\title{
Plant species survival on three water conserving green roofs in a hot humid subtropical climate
}

\author{
Bruce Dvorak $^{1}$, Brooke Byerley ${ }^{2}$, Astrid Volder $^{3}$ \\ ${ }^{1}$ Assistant Professor, Texas A\&M University, College Station, TX, bdvorak@tamu.edu \\ ${ }^{2}$ Botanist, Botanical Research Institute of Texas, Fort Worth, TX, bbyerley@brit.org \\ ${ }^{3}$ Associate Professor, Texas A\&M University, College Station, TX, $\underline{\text { a-volder@ tamu.edu }}$
}

Dvorak, B., Byerley, B., Volder, A., 2013. Plant species survival on three water conserving green roofs in a hot humid subtropical climate. Journal of Living Architecture. 1(1): 39-53.

http://greenroofs.org/resources/JOLA2013Volume1(Issue1)Dvorak(etal) 


\begin{abstract}
The quantification of ecological services from green roofs in Texas is emergent and proving advantageous. Identification of candidate plant species for green roofs in Texas and similar hot and humid subtropical climates is limited. Three extensive green roof systems and research sites in Texas employed different water conserving techniques ranging from no irrigation, to sparse application during dry and drought periods, to frequent watering with harvested rainwater. Thirty-four candidate species were identified for hot and humid climates from among the three sites. These findings help to establish a reference point for future investigations of green roof plant survivability.
\end{abstract}

Keywords: extensive, native, drought, rainwater harvesting, ecoroof

\title{
Introduction
}

The adoption of green roof technology in Texas is emergent and proving advantageous. (Simmons et al. 2008; Aitkenhead-Peterson et al. 2010; Dvorak and Volder 2010; Dvorak and Volder 2012a; Dvorak and Volder 2012b; Volder and Dvorak 2013). Current knowledge of candidate plant species on green roofs in Texas is limited (Dvorak and Volder 2012a). Water as a municipal resource will continue to become more scarce and costly in Texas due to urban growth and climate change (Pittman et al. 2007). To preserve municipal water, water conservation practices are encouraged, especially regarding irrigation (Pittman et al. 2007). Biodiversity and the persistence of native plants within urban centers is also in decline in Texas and elsewhere (Campbell 1995; Brennan and Kuvlesky 2005). Green roofs can be designed to function like natural ecosystems with limited external resources (Oberndorfer et al. 2007; Köhler 2009); however, there are few examples of this approach in Texas. With municipal water becoming more scarce and native plants in urban centers in decline, we explore drought-tolerant, native, and non-native plant species as candidates for populating green roofs in Texas. The outcomes of this investigation will help identify potential plant species for use on green roofs in hot and humid subtropical climates.

\section{Materials and Methods}

We report the survival of plants established among three geographical regions of Texas (north, central, and south) within a hot, humid, subtropical climate. Each investigation used different materials, establishment methods, and approaches to watering including: no irrigation, restricted irrigation with harvested rainwater, and frequent irrigation with harvested rainwater. The methods of study varied per site, as did the size, height above grade, type of roof system, and length of study (Table 1). The climate was drier and warmer than normal for many months throughout the investigation periods for sites, including record drought and high temperatures during 2011 (Nielsen-Gammon, McRoberts, and Pazos 2010; Nielsen-Gammon 2011).

Table 1. Conditions at three extensive roof study sites in Texas. 


\begin{tabular}{|c|c|c|c|}
\hline & Fort Worth, Texas & College Station, Texas & Friendswood, Texas \\
\hline Site location & $32^{\circ} 44^{\prime} \mathrm{N}, 97^{\circ} 21^{\prime} \mathrm{W}$ & $30^{\circ} 37^{\prime} \mathrm{N}, 96^{\circ} 20^{\prime} \mathrm{W}$ & $29^{\circ} 29^{\prime} \mathrm{N}, 95^{\circ} 12^{\prime} \mathrm{W}$ \\
\hline Roof height & 2-storey & 4-storey & 1 -storey \\
\hline System type & modular coconut fiber trays & modular plastic trays & monolithic \\
\hline Green roof size & $1083 \mathrm{~m}^{2}\left(11,400 \mathrm{ft}^{2}\right)$ & $\begin{array}{l}0.37 \mathrm{~m}^{2}\left(4 \mathrm{ft}^{2}\right) / \text { tray; } \\
21 \text { trays }\end{array}$ & $\begin{array}{l}107 \mathrm{~m}^{2}\left(1,156 \mathrm{ft}^{2}\right) \\
3 \text { sub-roofs }\end{array}$ \\
\hline Plants (\# spp., type) & $\begin{array}{l}38 \text { native spp. from local } \\
\text { limestone prairies (forbs, } \\
\text { graminoids, \& succulents) }\end{array}$ & $\begin{array}{l}22 \text { spp. (10 native to } \\
\text { Texas, } 12 \text { exotic) (forbs, } \\
\text { graminoids, succulents, } \\
\text { bulb, creeping shrub) }\end{array}$ & $\begin{array}{l}8 \text { exotic drought-resistant } \\
\text { spp. (forbs) }\end{array}$ \\
\hline Media depth & $12.5 \mathrm{~cm}$ (trays \& below) & $8.9 \mathrm{~cm}$ & $15 \mathrm{~cm}$ \\
\hline Media contents & $\begin{array}{l}\text { In trays: } 3.8-\mathrm{cm} \text { layer } 1: 1 \\
\text { calcareous sandy loam topsoil } \\
\text { (CSL) and hadite; a } 2.5-\mathrm{cm} \\
\text { layer of } 1: 1: 2 \text { CSL, hadite, and } \\
\text { limestone topsoil; and } 1.2-\mathrm{cm} \\
\text { gravel mulch. Below trays: } 5 \\
\text { cm } 1: 1 \text { CSL and LiteTop mix } \\
\text { (American Hydrotech, Inc.). } \\
\text { Media not FLL tested. }\end{array}$ & $\begin{array}{l}\text { Rooflite } \odot \text { lightweight } \\
\text { aggregate blend, FLL } \\
\text { compliant with aggregate } \\
\text { granulometric distribution, } \\
\text { porosity, moisture holding } \\
\text { and drainage capacity, } \\
\text { nutrient and organic } \\
\text { content, and stability. }\end{array}$ & $\begin{array}{l}60 \% \text { expanded shale, } 30 \% \\
\text { leaf mold compost, } 10 \% \\
\text { enriched loam, } 1.25 \text { pound } \\
\text { per yard; Microlife } \\
\text { Ultimate fertilizer (8-4-6), } \\
0.25 \text { pound per yard ECO- } \\
\text { MIN (Camerino, Brouwer, } \\
\text { and Volder 2010). Media } \\
\text { not FLL tested. }\end{array}$ \\
\hline $\begin{array}{l}\text { Establishment } \\
\text { irrigation }\end{array}$ & $\begin{array}{l}15.7 \mathrm{~mm} / \text { wk for } 12 \mathrm{mo} \\
\text { intermittent \& sparse thereafter }\end{array}$ & $\begin{array}{l}0-5.3 \mathrm{~mm} / \text { wk for } 2 \text { or } 8 \\
\text { wks; no irrigation } \\
\text { thereafter }\end{array}$ & $\begin{array}{l}12.7 \mathrm{~mm} / \mathrm{wk} \text { for } 6 \mathrm{mo} \text {; } \\
\text { then } 25.4 \mathrm{~mm} / \text { day for half } \\
\text { of all plants and no } \\
\text { irrigation for remaining } \\
\text { half (Camerino, Brouwer, } \\
\text { and Volder 2010). }\end{array}$ \\
\hline $\begin{array}{l}\text { USDA Cold } \\
\text { Hardiness }\end{array}$ & Zone $8 \mathrm{a}\left(-12.2\right.$ to $\left.-9.4^{\circ} \mathrm{C}\right)$ & Zone $8 \mathrm{~b}\left(-9.4\right.$ to $\left.-6.7^{\circ} \mathrm{C}\right)$ & Zone $9 \mathrm{a}\left(-6.7\right.$ to $\left.-3.9^{\circ} \mathrm{C}\right)$ \\
\hline $\begin{array}{l}\text { *30-yr. mean Aug } \\
\text { max. temp. }\end{array}$ & & $35.61{ }^{\circ} \mathrm{C}$ & $34.7^{\circ} \mathrm{C}$ \\
\hline $\begin{array}{l}\text { *30-yr. mean Jan } \\
\text { min temp. }\end{array}$ & $1.9^{\circ} \mathrm{C}$ & $4.8^{\circ} \mathrm{C}$ & $5.8^{\circ} \mathrm{C}$ \\
\hline $\begin{array}{l}\text { *Precipitation } \\
\text { during trial period }\end{array}$ & $\begin{array}{l}491 \mathrm{~mm}, \text { Aug-Dec, } 2010 \\
687 \mathrm{~mm}, 2011(-) \\
579 \mathrm{~mm}, \text { Jan-Jul, } 2012\end{array}$ & \begin{tabular}{|l|}
$508 \mathrm{~mm}, 2011(-)$ \\
$1102 \mathrm{~mm}, 2012$ \\
$242 \mathrm{~mm}, \mathrm{Jan}-\mathrm{Apr}, 2013$
\end{tabular} & $1193 \mathrm{~mm}, 2009$ \\
\hline
\end{tabular}

\begin{tabular}{|l|l|l|l|}
\hline & \multicolumn{1}{|c|}{ Fort Worth, Texas } & \multicolumn{1}{|c|}{ College Station, Texas } & \multicolumn{1}{c|}{ Friendswood, Texas } \\
\hline $\begin{array}{l}\text { *Comparison to } \\
\text { normal precipitation } \\
\text { depths }\end{array}$ & $\begin{array}{l}10 \%(+/-) \text { or greater deviation } \\
\text { from the monthly or annual } \\
\text { mean }\end{array}$ & $\begin{array}{l}10 \%(+/-) \text { or greater } \\
\text { deviation from the } \\
\text { monthly or annual mean }\end{array}$ & normal \\
\hline $\begin{array}{l}\text { Trial period (start- } \\
\text { end) }\end{array}$ & Jul 2010-Jul 2012 & Apr 2011-Apr 2013 & Jan 2009-Oct 2009 \\
\hline Total length of trial & 24 mo & 24 mo & 9.5 mo \\
\hline $\begin{array}{l}\text { Assessment of plant } \\
\text { success }\end{array}$ & \% of subplots with sp. present & $\begin{array}{l}\text { no. present/no. planted } \\
* 100\end{array}$ & $\begin{array}{l}\text { no. present/no. planted } \\
* 100\end{array}$ \\
\hline
\end{tabular}

*For detailed climate data see: Dvorak, Bruce, Brooke Byerley, and Astrid Volder. 2012. Plant Species Findings from Three Water Conserving Green Roofs in Texas. In Cities Alive!: 10th Annual Green Roof \& Wall Conference. Chicago: Cardinal Group, Toronto.

\section{PLANT SELECTION}

Sedum spp. are a popular choice for extensive green roofs and have been researched on a diversity of green roof systems in cool continental climates (Köhler 2006; Snodgrass and 
Snodgrass 2006; Durhman, Rowe, and Rugh 2007; Butler and Orians 2011; Barker and Lubell 2012; Rowe, Getter, and Durhman 2012). In the hot, humid, subtropical climate of Texas, very little has been published regarding Sedum spp. (Dvorak and Volder 2012a), and publication of candidate plants for green roofs in Texas is limited. Both the ASTM E 2400 Standard Guide for Selection, Installation, and Maintenance of Plants for Green Roof Systems and the German Guidelines for the Planning, Construction and Maintenance of Green Roofing recommend using native or non-invasive exotic or naturalized succulents, small grasses, and forbs on shallow (10$15 \mathrm{~cm}$ ) green roofs (ASTM E 2400 2006; FLL 2008). For deeper substrates $(15-35 \mathrm{~cm}$ ), the development of naturalized meadow and grass-based plant communities is possible (FLL 2008) and important for habitat preservation (Dunnett and Kingsbury 2004). The researchers of the three Texas sites had few sources of green roof plant research from the region to inform species selection; therefore, out of the hundreds of plausible species and sub-species reviewed by the researchers, final selection was sometimes based upon informed speculation. Most species selected for the investigations were characterized as drought tolerant, cold hardy to the region, available, and visually attractive. Some of the species had been pre-tested as described below.

\section{CANDIDATE SPECIES THRESHOLD}

Candidate species identified in the results and discussion section are species with at least $25 \%$ survival during the experimental periods (or survival within at least $25 \%$ of subplots sampled) or establishment from seed. Species in the unsuccessful list are those with less than $25 \%$ survival and otherwise performed poorly. Species survival rates were measured at the end of the study period.

Twenty-five percent species survival will likely fail to meet the industry standard of $80 \%$ (FLL 2008) vegetative cover of a green roof. Assuming that some species at the study sites may not establish and the exposed media where live plants once grew could negatively stress adjacent species during drought or warmer than normal conditions (Bates, Sadler, and Mackay 2013), we set the threshold low to include species that demonstrated some potential for survival or garnered recommendation for further investigation. The Fort Worth and College Station sites had stringent watering practices, and therefore some of the species that exhibited marginal success without irrigation might be worthy of further investigation since the sites were under record drought and heat stress during much of 2011 (Nielsen-Gammon 2011).

\section{EXPERIMENTAL GREEN ROOF \#1-FORT WORTH, TEXAS}

The $1,083 \mathrm{~m}^{2}\left(11,400 \mathrm{ft}^{2}\right)$ Fort Worth research site $\left(32^{\circ} 44^{\prime} \mathrm{N}, 97^{\circ} 21^{\prime} \mathrm{W}\right)$ (Figure 1) is located on top of a two-storey building at the Botanical Research Institute of Texas. Approximately 5,700 modular coconut fiber trays (BioTray, Tremco Roofing) were planted in July 2010. Each $0.19 \mathrm{~m}^{2}$ $\left(2 \mathrm{ft}^{2}\right)$ tray contained six native Texas species (five 10-cm transplants and a sixth annual species from seed) from a list of 38 total test species. Test species were chosen based on their persistence in thin, dry soils in the nearby Walnut and Goodland Limestone Prairie Barrens. Each tray has $7.5 \mathrm{~cm}$ depth of native soil for growing media and $5 \mathrm{~cm}$ of engineered media below the trays. Engineered media consisted of 1:1 calcareous sandy loam topsoil (CSL) and commercial 
aggregate media (LiteTop mix; American Hydrotech, Inc.). Media within the trays consisted of a lower 3.8-cm layer of 1:1 CSL and hadite; an upper 2.5-cm layer of 1:1:2 CSL, hadite, and biologically active Goodland Limestone topsoil harvested from a local prairie; and a 1.2-cm gravel mulch layer on top. Layered between the media and monolithic roof membrane were a fine mesh filter fabric, an aggregate-filled drainage layer (Gardendrain GR30 and LiteTop Aggregate; American Hydrotech, Inc.), polystyrene foam insulation, a drainage mat (Hydrodrain 300, American Hydrotech, Inc.), and a copper-based root protection sheet (Hydroflex RBII, American Hydrotech, Inc.). The drainage system was designed to retain $7.61 / \mathrm{m}^{2}$ with a flow rate of $479 \mathrm{l} / \mathrm{min} / \mathrm{m}$.

Figure 1. Fort Worth research site photographed on April 26, 2011.

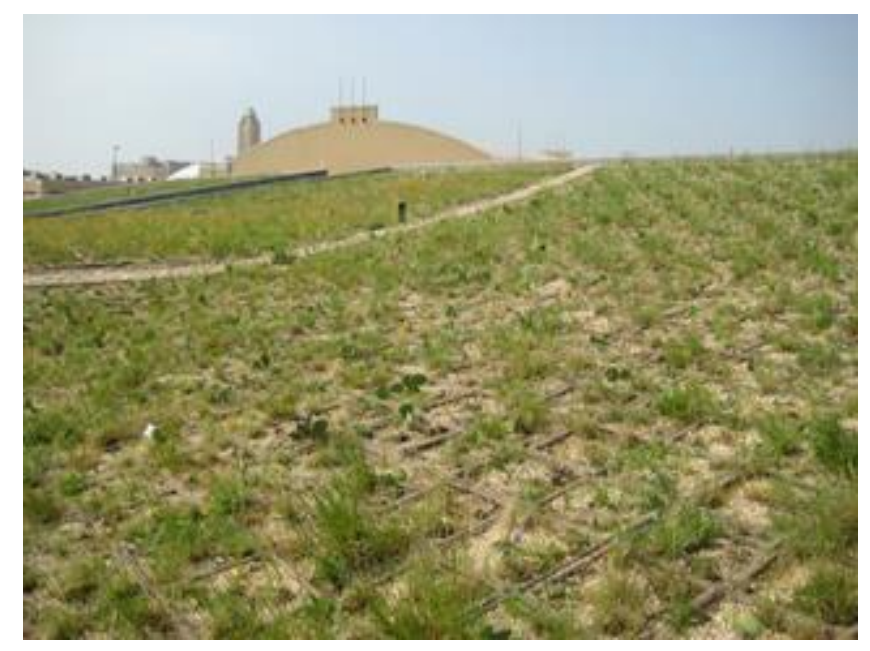

One hundred percent non-municipal irrigation was achieved by using harvested stormwater from the roof and parking lot and an on-site underground spring. In addition to $1500 \mathrm{~mm}$ of natural rainfall occurring over the entire 24 mo study period, all plants received approximately 15.7 $\mathrm{mm} / \mathrm{wk}$ supplemental, dry-season irrigation (May-Aug) during the first 12 months of establishment (Aug 2010-Aug 2011), with additional irrigation during extreme drought conditions in June-July 2011. At the end of the growing season, irrigation tapered to 7.85 $\mathrm{mm} / \mathrm{wk}$ for two weeks and then ceased completely until the beginning of the following dry season (May 2012) when occasional, minimal irrigation was provided as needed (e.g. $7.85 \mathrm{~mm}$ every 2-4 weeks). Plant survival was assessed 18-24 months after initial planting during MarchJuly 2012 using centralized replicate sampling where twenty-seven $0.25 \mathrm{~m}^{2}$ roof plots were subjectively chosen within homogenous, predetermined planting areas. Every species in each of these plots was identified and documented.

\section{EXPERIMENTAL GREEN ROOF \#2-COLLEGE STATION, TEXAS}

The College Station $\left(30^{\circ} 37^{\prime} \mathrm{N}, 96^{\circ} 20^{\prime} \mathrm{W}\right)$ research site (Figure 2$)$ is located on top of a fourstorey building at Texas A\&M University. Twenty-one 11.2-cm-deep modular green roof trays were investigated over three growing seasons. The $0.37 \mathrm{~m}^{2}\left(4 \mathrm{ft}^{2}\right)$ plastic trays (TectaAmerica Corp, Skokie, IL) each contained a $8.9 \mathrm{~cm}$ depth of FLL-compliant growing media for extensive 
green roofs (Rooflite ${ }^{\circledR}$ drain, Skyland USA LLC), a non-woven moisture retention geotextile, and thirty-six $2.5 \mathrm{~cm}$ deep drainage retention cups filled with expanded shale. Drainage for each tray is facilitated from twelve $0.95 \mathrm{~cm}$ (diameter) holes located about $2 \mathrm{~cm}$ above the bottom of the drainage retention cups. Water-holding capacity is rated at $24.4 \mathrm{~mm}$ depth of water if the water retention cells are left void. The trays were designed to both retain moisture for plants and reduce stormwater runoff. Trays were irrigated with $5.3 \mathrm{~mm}$ of potable water once a week as needed during the first two to eight weeks of plant establishment and only natural rainfall thereafter. Total precipitation during the evaluation periods was $508 \mathrm{~mm}$ in 2011 (driest and warmest on record; Nielsen-Gammon 2011), $1102 \mathrm{~mm}$ in 2012, and $242 \mathrm{~mm}$ from January to April 2013. Plant species were selected based upon discussions with green roof plant experts, available books, and web and peer-reviewed resources. Species survival rates were calculated by the number of plants present divided by the number of plants installed, multiplied by 100 .

Figure 2. College Station research site photographed on April 1, 2013. Manfreda maculosa in bloom on the left.

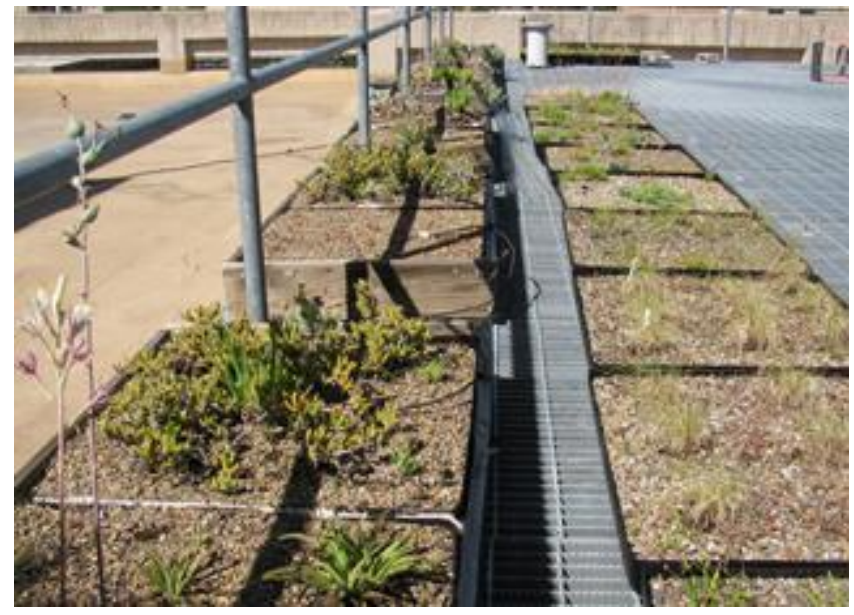

\section{EXPERIMENTAL GREEN ROOF \#3-FRIENDSWOOD, TEXAS}

The investigation in Friendswood, Texas $\left(29^{\circ} 29^{\prime} \mathrm{N}, 9^{\circ} 12^{\prime} \mathrm{W}\right)$, was located on a one-storey building (Figure 3). Three green sub-roofs on an existing green roof were planted with eight drought-resistant species produced by Ozbreed Ltd, an Australia-based plant breeding company (Camerino, Brouwer, and Volder 2011). The plugs were planted in three groups of six (one group on each sub-roof for a total of 18 plants) into existing green roof media that was $15 \mathrm{~cm}$ deep and composed of expanded shale (60\%), leaf mold compost (30\%), and enriched loam (10\%), as well as $0.6 \mathrm{~kg} \mathrm{~m}^{-2}$ Microlife Ultimate fertilizer (8-4-6) (Camerino, Brouwer, and Volder 2011). Plants were planted on January 15, 2009, and irrigated with water recycled from the roof and parking lot three times per week at $4.2 \mathrm{~mm}$ per irrigation (12.7 mm per week) until July 19, 2009. During this period a total of $619 \mathrm{~mm}$ in rainfall was recorded. On July 19, half of the surviving plants stopped receiving irrigation, while the other half received $25.4 \mathrm{~mm}$ drip irrigation per day (daily complete saturation of the growth media, as practiced by the building owner on other areas of the roof). Survival rates were calculated by the number of plants present divided by the number of plants installed multiplied by 100. Plant survival was measured on July 19, 2009, and October 30, 2009, and total precipitation during the growing period was $1193 \mathrm{~mm}$ 
(Camerino, Brouwer, and Volder 2011). Health quality ratings were assigned by teams of master gardener volunteers using a scale from 0 to 9, with 0 indicating a dead plant, 6 indicating an acceptable quality, and 9 indicating a perfect plant with no blemishes (Camerino, Brouwer, and Volder 2011).

Figure 3. One of three sub-roofs at Friendswood research site, photographed on July 6, 2009.

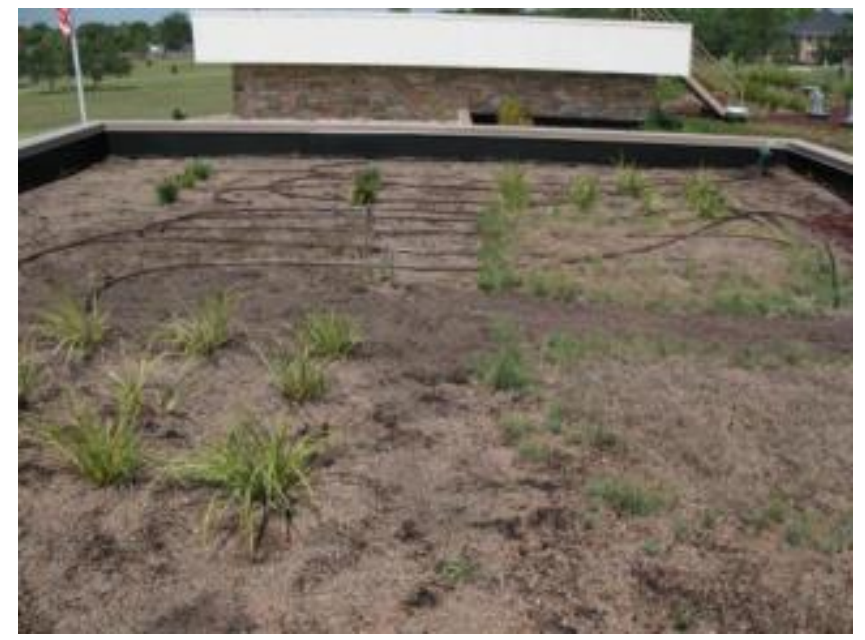

\section{Results and Discussion}

Thirty-four candidate species have been identified for potential use on extensive green roofs in Texas and similar climates (Tables 2, 3, and 4). These results are from a limited data set and short-term establishment periods. Actual performance in similar climates may vary depending upon green roof substrate design, irrigation regimes, maintenance practices, and departure from the climate norms during establishment. Since each research site is in a different USDA cold hardiness zone (Table 1) and each green roof set up was different, the candidate species should be considered specific to the location.

\section{EXPERIMENTAL GREEN ROOF \#1-FORT WORTH, TEXAS}

Fifteen candidate species were identified at the North Texas research site in Fort Worth (Table 2). These include 7 forbs, 4 graminoids, and 4 succulents. Four species did not survive in the form of the original transplants but germinated and persisted in small numbers presumably from latent seeds imported with the native prairie topsoil. These species are differentiated in Table 2 (with an asterisk), and though none are listed as candidate transplant species, some could potentially prove viable for roof systems after further evaluation over multiple consecutive seasons. In addition to exhibiting high survival rates, four species were identified as exceptional in terms of qualitative measures of speed of establishment and general proliferation (both vegetative and reproductive). These were Bouteloua curtipendula var. curtipendula, Bouteloua dactyloides, Muhlenbergia reverchonii, and Opuntia phaeacantha. 
Several unsuccessful species, such as Aristida pupurpea, Asclepias asperula, Convolvulus equitans, and Oenothera macrocarpa, were expected to perform well due to their pervasiveness in the native Walnut and Goodland Limestone habitats upon which this roof system was modeled (Swadek and Burgess 2012). These species also failed to establish despite their assumed presence in the seed bank (all species were present at the soil harvest site), thus we cannot say that these species simply failed due to poor quality of transplants or transplant shock. Continuous monitoring of plant watering was practiced to efficiently apply irrigation only when needed.

Table 2. Fort Worth species scientific and common names, nativity and lifeform of species (N=native, E=exotic), ranked by survival rate (SR) for July 2010 to July 2012. Candidate species are species with at least 25\% survival at the end of the trial period. $*=$ species that failed as transplants but persisted from the seed bank.

\begin{tabular}{|c|c|c|c|c|}
\hline $\begin{array}{l}\text { Genera } \\
\text { Candidate } \\
\text { Species }\end{array}$ & Species & $\begin{array}{l}\text { Common } \\
\text { Name }\end{array}$ & $\begin{array}{l}\text { Nativity/ } \\
\text { Life-form }\end{array}$ & SR \\
\hline Escobaria & missouriensis & Missouri foxtail & N/succulent & 100 \\
\hline Gaillardia & pulchella & $\begin{array}{l}\text { Indian } \\
\text { blanketflower }\end{array}$ & $\mathrm{N} /$ forb & $100 /$ seed \\
\hline Heliotropium & tenellum & $\begin{array}{l}\text { pasture } \\
\text { heliotrope }\end{array}$ & $\mathrm{N} /$ forb & 100 \\
\hline Lupinus & texensis & $\begin{array}{l}\text { Texas } \\
\text { bluebonnet }\end{array}$ & $\mathrm{N} /$ forb & $100 /$ seed \\
\hline Opuntia & phaeacantha & $\begin{array}{l}\text { desert prickly } \\
\text { pear }\end{array}$ & $\mathrm{N} /$ succulent & 100 \\
\hline Phemeranthus & calcaricus & fameflower & $\mathrm{N} /$ succulent & 100 \\
\hline Yисса & pallida & pale yucca & N/succulent & 100 \\
\hline Tridens & $\begin{array}{l}\text { muticus var. } \\
\text { elongatus }\end{array}$ & slim tridens & N/graminoid & 95 \\
\hline Bouteloua & $\begin{array}{l}\text { curtipendula var. } \\
\text { curtipendula }\end{array}$ & sideoats grama & N/graminoid & 90 \\
\hline Bouteloua & dactyloides & buffalograss & N/graminoid & 90 \\
\hline Muhlenbergia & reverchonii & seep muhly & N/graminoid & 90 \\
\hline Phyla & nodiflora & frog fruit & $\mathrm{N} /$ forb & 90 \\
\hline Tetraneuris & scaposa & $\begin{array}{l}\text { stemmy } \\
\text { hymenoxys }\end{array}$ & N/forb & 90 \\
\hline Liatris & aestivalis & blazing-star & $\mathrm{N} /$ forb & 80 \\
\hline Thelesperma & filifolium & greenthread & $\mathrm{N} /$ forb & $50 /$ seed \\
\hline \multicolumn{5}{|l|}{$\begin{array}{l}\text { Unsuccessful } \\
\text { species }\end{array}$} \\
\hline Erioneuron & pilosum & $\begin{array}{l}\text { hairy } \\
\text { woollygrass }\end{array}$ & N/graminoid & $15^{*}$ \\
\hline Hedeoma & reverchonii & $\begin{array}{l}\text { Reverchon's } \\
\text { false } \\
\text { pennyroyal }\end{array}$ & N/forb & $15^{*}$ \\
\hline Glandularia & bipinnatifida & verbena & $\mathrm{N} /$ forb & $5^{*}$ \\
\hline Нутепорарриs & tenuifolius & chalk-hill & N/forb & $5^{*}$ \\
\hline
\end{tabular}


Table 2. Fort Worth species scientific and common names, nativity and lifeform of species ( $\mathrm{N}=$ native, $\mathrm{E}=$ exotic), ranked by survival rate (SR) for July 2010 to July 2012. Candidate species are species with at least $25 \%$ survival at the end of the trial period. $*=$ species that failed as transplants but persisted from the seed bank.

\begin{tabular}{|c|c|c|c|c|}
\hline Genera & Species & $\begin{array}{l}\text { Common } \\
\text { Name } \\
\text { woolly white }\end{array}$ & $\begin{array}{l}\text { Nativity/ } \\
\text { Life-form }\end{array}$ & SR \\
\hline Digitaria & cognata & fall witchgrass & N/graminoid & 2 \\
\hline Marshallia & caespitosa & puffballs & $\mathrm{N} /$ forb & 2 \\
\hline Minuartia & michauxii & $\begin{array}{l}\text { Michaux's } \\
\text { stitchwort }\end{array}$ & $\mathrm{N} /$ forb & 2 \\
\hline Aristida & purpurea & $\begin{array}{l}\text { purple three- } \\
\text { awn }\end{array}$ & N/graminoid & 0 \\
\hline Asclepias & asperula & antelope horns & $\mathrm{N} /$ forb & 0 \\
\hline Callirhoe & involucrata & winecup & N/forb & 0 \\
\hline Carex & planostachys & cedar sedge & N/graminoid & 0 \\
\hline Convolvulus & equitans & $\begin{array}{l}\text { Texas } \\
\text { bindweed }\end{array}$ & N/forb & 0 \\
\hline Dichanthelium & $\begin{array}{l}\text { oligosanthes var. } \\
\text { scribnerianum }\end{array}$ & $\begin{array}{l}\text { Scribner's } \\
\text { rosette grass }\end{array}$ & N/graminoid & 0 \\
\hline Dyschoriste & linearis & polkadots & $\mathrm{N} /$ forb & 0 \\
\hline Oenothera & macrocarpa & $\begin{array}{l}\text { Missouri } \\
\text { evening- } \\
\text { primrose }\end{array}$ & $\mathrm{N} /$ forb & 0 \\
\hline
\end{tabular}

\section{EXPERIMENTAL GREEN ROOF \#2-COLLEGE STATION, TEXAS}

Eleven candidate species were identified for south-central Texas (Table 3). Six species had no losses without irrigation including Graptopetalum paraguayense, Malephora lutea, Manfreda maculosa, Phemeranthus calycinus, Portulaca pilosa, and Sedum album. Phemeranthus calycinus and Portulaca pilosa were successful in establishing child plants, a desirable function for extensive green roofs. Seven species had some survivors including Bulbine frutescens, Delosperma cooperi, Lampranthus spectabilis 'Red Shift', Lupinus texensis, and Sedum kamtschaticum, but these may need some irrigation during periods of extended drought or excessive heat. One species Nassella tenuissima had a survival rate of seventeen percent and did not make it to the candidate list, but may be worth further investigation because the climate during the study period was the driest and warmest on record (Nielsen-Gammon 2011), and this species grows without irrigation across the state. Nine species had no surviving plants including Allium senescens 'Glaucum', Delosperma nubigenum 'Basutoland', Delosperma 'Psfave', Dichondra argentea, Stemodia lanata, Myoporum parvifolium, Sedum mexicanum, Sedum moranense, Sedum moranense 'Grandiflorum', and Sedum tetractinum. 
Since some of these species are known to grow in the wild in the region without irrigation, it is possible that some of the species may have performed better if the soil was protected with vegetative cover (Butler and Orians 2009) or received some watering during dry and hot periods (Durhman, Rowe, and Rugh 2006; Wolf and Lundholm 2008).

The short-term watering periods during the first two weeks to two months required frequent observation of plant health and weather forecasts. If there was a high chance of precipitation on or near a watering day, irrigation was not applied. If the anticipated rain did not occur, then watering was applied.

Table 3. College Station species scientific and common names, nativity and lifeform of species ( $\mathrm{N}=$ native, $\mathrm{E}=$ exotic) and rank by survival rate (SR) from Apr 2011-Apr 2013. Candidate species are species with at least $25 \%$ survival at the end of the trial period. Species greater than one hundred percent produced child plants without irrigation. Asterisk denotes species watered only for two weeks after planting; other species were watered for two months.

\begin{tabular}{|c|c|c|c|c|}
\hline Genera & Species & Common & $\begin{array}{l}\text { Nativity/ } \\
\text { Life-form }\end{array}$ & SR \\
\hline \multicolumn{5}{|l|}{$\begin{array}{l}\text { Candidate } \\
\text { Species }\end{array}$} \\
\hline Portulaca & pilosa & kiss me quick & $\mathrm{N} /$ succulent & 360 \\
\hline Phemeranthus & calycinus & fameflower & N/succulent & 139 \\
\hline Malephora & lutea & $\begin{array}{l}\text { rocky point ice } \\
\text { plant }\end{array}$ & E/succulent & 120 \\
\hline Delosperma & cooperi & trailing iceplant & E/succulent & 100 \\
\hline Graptopetalum & paraguayense & ghost plant & E/succulent & 100 \\
\hline Manfreda & maculosa & spice lily & $\mathrm{N} /$ forb & 100 \\
\hline Lampranthus & $\begin{array}{l}\text { spectabilis 'Red } \\
\text { Shift' }\end{array}$ & ice plant & E/succulent & 70 \\
\hline \multicolumn{5}{|l|}{$\begin{array}{l}\text { Candidate } \\
\text { Species }\end{array}$} \\
\hline *Sedum & album f. 'Murale' & white stonecrop & E/succulent & 67 \\
\hline Sedum & kamtschaticum & stonecrop & E/succulent & 27 \\
\hline *Bulbine & frutescens & African bulbine & E/succulent & 25 \\
\hline Lupinus & texensis & $\begin{array}{l}\text { Texas } \\
\text { bluebonnet }\end{array}$ & N/forb & 25 \\
\hline
\end{tabular}

\section{Unsuccessful species}

Nassella

*Allium

*Delosperma

*Delosperma

Dichondra

tenuissima
senescens 'Glaucum'
'Psfave' (Lavender
Ice)
nubigenum
'Basutoland'
argentea

Mexican feather grass circle onion

lavender ice

ice plant

dichondra
N/graminoid $\quad 17$

E/bulb

0

E/succulent $\quad 0$

E/succulent $\quad 0$

$\mathrm{N} /$ forb

17
0
0
0
0




\begin{tabular}{lllll}
\hline Genera & Species & Common & $\begin{array}{l}\text { Nativity/ } \\
\text { Life-form }\end{array}$ & SR \\
Myoporum & parvifolium & $\begin{array}{l}\text { creeping } \\
\text { boobialla }\end{array}$ & E/creeping shrub & 0 \\
Sedum & mexicanum & $\begin{array}{l}\text { Mexican } \\
\text { stonecrop } \\
\text { red stonecrop }\end{array}$ & N/succulent & 0 \\
*Sedum & $\begin{array}{l}\text { moranense } \\
\text { moranense }\end{array}$ & red stonecrop & N/succulent & 0 \\
*Sedum & $\begin{array}{l}\text { 'Grandiflorum' } \\
\text { tetractinum }\end{array}$ & Chinese sedum & E/succulent & 0 \\
*Sedum & lanata & woolly stemodia & N/forb & 0 \\
Stemodia & & & & 0 \\
\hline
\end{tabular}

\section{EXPERIMENTAL GREEN ROOF \#3-FRIENDSWOOD, TEXAS}

During initial establishment of the eight drought-tolerant exotic forbs, only four cultivars showed some mortality. Lomandra longifolia 'Katrinus Deluxe' performed the worst with only 50\% establishment, while Dianella revoluta 'Baby Bliss' had a 67\% establishment rate and Lomandra hystrix 'Tropic Belle' and Lomandra longifolia 'Katrinus Deluxe' had an 83\% establishment rate (Table 3) (Camerino, Brouwer, and Volder 2011). Surprisingly, after initial establishment (January 15-July 19, 2009) no more plants were lost between then and October 30, 2009, regardless of irrigation. Plants received $575 \mathrm{~mm}$ in rainfall between July 19 and October 30, 2009 (Camerino, Brouwer, and Volder 2011). Overall health quality rating at the end of the summer (October 30, 2009) was highest for Dianella caerulea 'Cassa Blue', Dianella revoluta 'Big Rev', and Dianella revoluta 'Little Rev', which were also cultivars that had a $100 \%$ survival rate throughout the trial. Quality ratings were not affected by irrigation treatment (Camerino, Brouwer, and Volder 2011).

Table 3. Friendswood species scientific and common names, nativity and lifeform of species ( $\mathrm{N}=$ native, $\mathrm{E}=$ exotic) and rank by survival rate (SR) from January 2009 to October 30, 2009. Candidate species are species with at least $25 \%$ survival at the end of the trial period.

\begin{tabular}{llllc}
\hline Genera & Species & Common & $\begin{array}{l}\text { Nativity/ } \\
\text { Life-form }\end{array}$ & SR \\
$\begin{array}{l}\text { Candidate } \\
\text { Species } \\
\text { Dianella }\end{array}$ & $\begin{array}{l}\text { caerulea 'Cassa } \\
\text { Blue' } \\
\text { revoluta 'Big Rev' }\end{array}$ & $\begin{array}{l}\text { Cassa blue } \\
\text { Dianella }\end{array}$ & $\begin{array}{l}\text { E/forb } \\
\text { Rev }\end{array}$ & 100 \\
Dianella & revoluta 'Little Rev' & $\begin{array}{l}\text { Dianella 'Little } \\
\text { Rev' }\end{array}$ & E/forb & 100 \\
Lomandra & 'Tropic Belle' & $\begin{array}{l}\text { Lomandra } \\
\text { Gary's green }\end{array}$ & E/forb & 100 \\
Lomandra & $\begin{array}{l}\text { Lomandra } \\
\text { 'Katrifolia 'Katrinus }\end{array}$ & E/forb & 100 \\
& Deluxe' & 'Katinus &
\end{tabular}




\begin{tabular}{|c|c|c|c|c|}
\hline Genera & Species & $\begin{array}{l}\text { Common } \\
\text { Deluxe' }\end{array}$ & $\begin{array}{l}\text { Nativity/ } \\
\text { Life-form }\end{array}$ & SR \\
\hline Dianella & 'Tasred' hystrix & Dianella 'Tasred' & E/forb & 83 \\
\hline Dianella & $\begin{array}{l}\text { revoluta 'Baby } \\
\text { Bliss' }\end{array}$ & $\begin{array}{l}\text { Dianella } \\
\text { revoluta 'Baby } \\
\text { Bliss' }\end{array}$ & E/forb & 67 \\
\hline Lomandra & longifolia 'Breeze' & $\begin{array}{l}\text { Lomandra } \\
\text { longifolia } \\
\text { 'Breeze' }\end{array}$ & E/forb & 50 \\
\hline
\end{tabular}

\section{SUMMARY}

Our findings identified thirty-four candidate species for establishment on extensive green roofs in the hot, humid, subtropical climate of the United States (i.e., Texas). Three green roofs used different watering approaches to establish plants that varied from no irrigation, to irrigation only during hot and dry periods with harvested rainwater, to irrigation applied multiple times per week with harvested rainwater. The range of designs with candidate species demonstrates that it may be possible to establish plants on green roofs in a hot, humid, subtropical climate with a range of conservation watering techniques. Since there was mortality at the no irrigation and limited irrigation sites and because some species take longer to establish than others, we recommend exploring the effect of more watering on species survival (Sutton et al. 2012).

Some species were found to reproduce on the green roof, a key attribute of ecoroof-based designs (Hauth and Liptan 2003). It was also observed that a water conservation approach to plant establishment requires attention to the communication of maintenance and watering practices to owners and managers of green roofs. Such an approach means that someone is occasionally observing the vegetation to make adjustments in watering based upon climatic conditions and plant health.

These findings help establish baseline expectations for establishing plants on green roofs in hot, humid, subtropical climates. Native and non-invasive exotic candidate species were identified as candidate species. We agree with others that preference should be given to native species in diverse forms, such as succulents, graminoids, and forbs where possible, to promote conservation of biodiversity (Simberloff 1998; Simmons, Venhaus, and Windhager 2007; Kowarik 2011; Sutton et al. 2012).

Further research on the candidate species is recommended since long-term research indicates that six to ten years or more may be necessary to begin to understand the persistence of species on green roofs (Köhler 2006; Dunnett and Nagase 2007; Köhler and Poll 2010; Rowe, Getter, and Durhman 2012). Our study is an initial step toward identifying species for such purposes in hot, humid, subtropical climates. 


\section{Literature Cited}

Aitkenhead-Peterson, Jacqueline, Bruce Dvorak, Astrid Volder, and Nina Stanley. 2010.

"Chemistry of Growth Medium and Leachate from Green Roof Systems in South-Central Texas." Urban Ecosystems no. 14 (1):1-17. doi: 10.1007/s11252-010-0137-4.

ASTM E 2400. 2006. Standard Guide for Selection, Installation, and Maintenance of Plants for Green Roof Systems. West Conshohochen, PA: ASTM International.

Barker, Kristoffer J., and Jessica D. Lubell. 2012. "Effects of Species Proportions and Fertility on Sedum Green Roof Modules." HortTechnology no. 22 (2):196-200.

Bates, Adam J., Jon P. Sadler, and Rae Mackay. 2013. "Vegetation Development over Four Years on Two Green Roofs in the UK." Urban Forestry \& Urban Greening no. 12 (1):98-108. doi: 10.1016/j.ufug.2012.12.003.

Brennan, Leonard A., and William P. Kuvlesky Jr. 2005. "Invited Paper: North American Grassland Birds: An Unfolding Conservation Crisis?" Journal of Wildlife Management no. 69 (1):1-13. doi: 10.2193/0022-541X(2005)069<0001:NAGBAU>2.0.CO;2.

Butler, Colleen, and Colin Orians. 2009. Sedum Facilitates the Growth of Neighboring Plants on a Green Roof under Water Limited Conditions. In Seventh Annual Greening Rooftops for Sustainable Communities Conference, Awards and Trade Show. Atlanta, GA: The Cardinal Group, Toronto.

Butler, Colleen, and Colin M. Orians. 2011. "Sedum Cools Soil and Can Improve Neighboring Plant Performance During Water Deficit on a Green Roof." Ecological Engineering no. 37 (11):1796-1803. doi: 10.1016/j.ecoleng.2011.06.025.

Camerino, Anthony W., Carol S. Brouwer, and Astrid Volder. 2011. Evaluation of Landscape Plants for Use on Green Roofs in the Texas Gulf Coast Area. In SNA Research Conference, edited by Gawel, Dr. Nick: Southern Nursery Association.

Campbell, Linda. 1995. Endangered and Threatened Animals of Texas: Their Life History and Management. Austin, Texas: Texas Parks \& Wildlife, Resource Protection Division, Endangered Resources Branch.

Dunnett, Nigel, and Noel Kingsbury. 2004. Planting Green Roofs and Living Walls. Portland, Oregon: Timber Press.

Dunnett, Nigel, and Ayako Nagase. 2007. The Dynamics and Visual Impact of Planted and Colonizing Species on a Green Roof over 6 Growing Seasons 2001-2006: Influence of Substrate Depth. In The Fifth Greening Rooftops for Sustainable Communities Conference. Minneapolis, MN: The Cardinal Group. 
Durhman, A. K., B. D. Rowe, and C. L. Rugh. 2006. "Effect of Watering Regimen on Chlorophyll Fluorescence and Growth of Selected Green Roof Plant Taxa." HortScience no. 41 (7):1623-1628.

Durhman, Angela K., Bradley D. Rowe, and Clayton L. Rugh. 2007. "Effect of Substrate Depth on Initial Growth, Coverage, and Survival of 25 Succulent Green Roof Plant Taxa." HortScience no. 42 (3):588-595.

Dvorak, Bruce, and Astrid Volder. 2010. "Green Roof Vegetation for North American Ecoregions: A Literature Review." Landscape and Urban Planning no. 96 (4):197-213.

Dvorak, Bruce, and Astrid Volder. 2012a. "Plant Establishment on Unirrigated Green Roof Modules in a Subtropical Climate." AoB Plants. doi: 10.1093/aobpla/pls049.

Dvorak, Bruce, and Astrid Volder. 2012b. "Rooftop Temperature Reduction from Unirrigated Modular Green Roofs in South-Central Texas." Urban Forestry \& Urban Greening no. 12 (1):28-35. doi: 10.1016/j.ufug.2012.05.004.

FLL. 2008. Guidelines for the Planning, Construction and Maintenance of Green Roofing. Bonn, Germany: Forschungsgesellschaft Landschaftsentwicklung Landschaftsbau e. V.

Hauth, Emily, and Tom Liptan. 2003. Plant Survival Findings in the Pacific Northwest. In The First North American Green Roof Infrastructure Conference: Greening Rooftops for Sustainable Communities. The Cardinal Group.

Köhler, Manfred. 2006. "Long-Term Vegetation Research on Two Extensive Green Roofs in Berlin." Urban Habitats no. 4 (1):3-26.

Köhler, Manfred. 2009. How Green Should a Green Roof Be? Extensive Green Roofs without Irrigation. In The Seventh Annual Greening Rooftops for Sustainable Communities Conference. Atlanta, GA.: The Cardinal Group, Toronto.

Köhler, Manfred, and Philipp H. Poll. 2010. "Long-Term Performance of Selected Old Berlin Greenroofs in Comparison to Younger Extensive Greenroofs in Berlin." Ecological Engineering no. 36 (5):722-729. doi: 10.1016/j.ecoleng.2009.12.019.

Kowarik, Ingo. 2011. "Novel Urban Ecosystems, Biodiversity, and Conservation." Environmental Pollution no. 159 (8-9):1974-1983. doi: 10.1016/j.envpol.2011.02.022.

Nielsen-Gammon, John. 2011. The 2011 Texas Drought: A Briefing Packet for the Texas Legislature October 31, 2011. Office of the State Climatologist, Texas: Texas A\&M University.

Nielsen-Gammon, John, Brent McRoberts, and Marissa Pazos. 2010. Texas Climatic Bulletin 2010. College Station, TX: Texas A\&M University.

Oberndorfer, Erica, Jeremy Lundholm, Brad Bass, Reid Coffman, Hitesh Doshi, Nigel Dunnett, Stuart Gaffin, Manfred Köhler, Karen Lui, and Bradley Rowe. 2007. "Green Roofs as Urban Ecosystems: Ecological Structures, Functions, and Services." Bioscience no. 57 (10):823-833. 
Pittman, R., J. Hunt, J. Herring, W. Meadows, T. Weir, D. Guerra, J. Ward, W. Mullican, and C. Brittin. 2007. Water for Texas 2007. Austin, TX: Texas Water Development Board.

Rowe, D. Bradley, Kristin L. Getter, and Angela K. Durhman. 2012. "Effect of Green Roof Media Depth on Crassulacean Plant Succession over Seven Years." Landscape and Urban Planning no. 104 (3-4):310-319. doi: 10.1016/j.landurbplan.2011.11.010.

Simberloff, Daniel. 1998. "Flagships, Umbrellas, and Keystones: Is Single-Species Management Passé in the Landscape Era?" Biological Conservation no. 83 (3):247-257. doi: 10.1016/S0006-3207(97)00081-5.

Simmons, Mark, Brian Gardiner, Steve Windhager, and Jeannine Tinsley. 2008. "Green Roofs Are Not Created Equal: The Hydrologic and Thermal Performance of Six Different Extensive Green Roofs and Reflective and Non-Reflective Roofs in a Sub-Tropical Climate." Urban Ecosystems no. 11 (4):339-348.

Simmons, Mark T., Heather C. Venhaus, and Steve Windhager. 2007. "Exploiting the Attributes of Regional Ecosystems for Landscape Design: The Role of Ecological Restoration in Ecological Engineering." Ecological Engineering no. 30:201-205.

Snodgrass, Edmond, and Lucie Snodgrass. 2006. Green Roof Plants. Portland, Oregon: Timber Press.

Swadek, Rebecca K., and Tony L. Burgess. 2012. "Vascular Flora of the North Central Texas Walnut Formation." Journal of the Botanical Research Institute of Texas no. 6:725-752.

Sutton, Richard K., John A. Harrington, Lee Skabelund, Peter MacDonagh, Reid R. Coffman, and Gord Koch. 2012. "Prairie-Based Green Roofs: Literature, Templates, and Analogs." Journal of Green Building no. 7 (1):143-172. doi: 10.3992/jgb.7.1.143.

Volder, Astrid, and Bruce Dvorak. 2013. "Event Size, Substrate Water Content and Vegetation Affect Storm Water Retention Efficiency of an Un-Irrigated Extensive Green Roof System in Central Texas." Sustainable Cities and Society (0). doi: 10.1016/j.scs.2013.05.005.

Wolf, Derek, and Jeremy T. Lundholm. 2008. "Water Uptake in Green Roof Microcosms: Effects of Plant Species and Water Availability." Ecological Engineering no. 33 (2):179186. doi: 10.1016/j.ecoleng.2008.02.008. 